\title{
THE TEARS \\ OF THE SINFUL WOMAN: A THEOLOGY OF REDEMPTION \\ IN THE HOMILIES \\ OF ST. EPHRAIM AND HIS FOLLOWERS
}

\author{
HANNAH M. HUNT \\ UNIVERSITY OF LEEDS \\ UNITED KINGDOM
}

\section{INTRODUCTION}

[1] Ephraim's Homily on the Sinful Woman, ${ }^{1}$ which gives an exegesis of Luke's account of the sinful woman who bathes the feet of Jesus with her penitent tears, ${ }^{2}$ is a remarkable piece of poetic theology in its own right. It also forms the inspiration for a number of other theological commentaries in Syriac. There are two dialogue-poems on the subject. ${ }^{3}$ Two anonymous homilies are edited by Graffin 1962; a third was projected but is not extant. There is one by Jacob of Serugh. ${ }^{4}$ Sauget 1975/6 provides a translation of another homily

${ }^{1}$ Johnston 1898, as well as the Homily on the Sinful Woman listed as number 3 in this translation; number 1, a Homily on Our Lord, devotes a substantial section to the same story.

${ }^{2}$ Luke 7:37-50.

${ }^{3}$ Beck, Sermones, II, no. 4, English Trans., Brock 1988.

${ }^{4}$ Amar, J. P. "A Metrical Homily on Holy Mar Ephrem by Mar Jacob of Sarug: Critical Edition of the Syriac Text, Translation and Introduction," Patrologia Orientalis 47, fasc. 1, no. 209 (Turnhout, 1995). 
"attributed to Bishop John," which may refer to Chrysostom, to whom is attributed another homily on the subject in Sahidic which survives. This Coptic text shares many stylistic points with the Syriac homilies, especially in developing the dialogue between the woman and Satan and the seller of perfumes, a peculiarly Ephraimic interpolation into the Lucan text.

The popularity of this Lucan story is attested by modern as well as ancient scholars. Sauget's introduction refers to the plethora of Byzantine homilies based on this text. Brock 1989: 144 notes that this story is one motif that found its way from Syriac literature into Greek texts. Carpenter, in her edition of the Kontakia of Romanos, 1970, notes that this was "a peculiarly oriental motif." 5 Ode 10 in this volume is on the sinful woman.

My contention is that this focus of interest may be accounted for in part by the Syrian tradition of typology and symbolism, which provides, in the person of the penitent woman, a model for the whole of sinful humanity. In the case of Ephraim, the focus on female characters reflects his sympathy for, and understanding of, the local and specific audience for which he was writing.

This paper, therefore, begins with a consideration of Ephraim's typology, and the conflation of several female characters in the New Testament. This sets the background for an assessment of the available homilies on the Lucan story, in which what the Greeks know as penthos is portrayed in its Syrian mode as grieving penitence. The symbolic mode of utterance which underlies these texts, reveals the individual's remorse for sinfulness expressed in inner dialogues, which, being externalized, invites healing.

\section{EPHRAIM’s LifE AND POETIC IDIOM}

The dangers of relying on Byzantine sources for information about the Syrian Fathers are well known, and nowhere are they more present than in the case of the life of Ephraim, where a deceptively full Vita exists, which is not, however, corroborated by internal evidence from Ephraim's own writings. ${ }^{6}$

${ }^{5}$ Carpenter 1970: 99.

6 Jerome, writing only two decades after Ephraim's death affirms his enduring importance to the Syrian Church. (Book of Illustrious Men, chapter 115) Both Palladius in the early fifth century (Lausiac History, chapter 40), and the slightly later Sozomen (Ecclesiastical History 3, 16) give 
His dates may be taken as c. 306 to 373 , and it is generally accepted that he was born into a Christian family, ordained as a deacon, and worked as a catechetical teacher, predominantly with women. The evidence for this comes from a verse panegyric by Jacob of Serugh, cited by Brock ${ }^{7}$ which describes Ephraim as "a second Moses for women folk." In his wisdom, he saw that it was appropriate for them to sing, and he composed hymns specifically for them. ${ }^{8} \mathrm{He}$ died not long after having assisted victims of famine. The three sieges of Nisibis feature significantly in his works, and he also comments on his relationships with significant bishops of the day in his hymns. The appeal of Ephraim's poetry has been recognized only relatively recently, according to Brock, ${ }^{9}$ who has played a large part in the renaissance of interest in his theological use of symbolism and paradox within well-crafted verse. It is as a "theologian-poet"10 that he should be read. His complex literary and linguistic devices, such as antithesis, paradox and puns, not only produce compellingly beautiful literature, but also illuminate his understanding of God. In particular, the focus in his writings

glowing accounts of his literary merits, and Theodoret (Ecclesiastical History 4, 29) and Gennadius (Supplement to Jerome's Book of Illustrious Men) make brief references to Ephraim. Outtier 1973 accepts to a great extent the authenticity of these Byzantine accounts; a more critical appraisal of their findings and other bibliographic suppositions may be found in Brock 1990: Intro. and in the same scholar's contribution to the next issue of Hugoye (Vol. 2, No. 1).

${ }^{7}$ Brock 1990: 22-4.

8 This panegyric notes that these women are enabled to do this through the work of the Second Eve, who has purged out the First Eve from them, an analogy much used by Ephraim himself. Brock notes Ephraim's affection for and interest in women, from which he infers that he is unlikely to have been a monk enclosed in a cell, avoiding even the sight of women, as the Life says. In addition, in the fourth century asceticism in Nisibis is more likely to have taken the form of what he terms "proto-monasticism" than of monaticism in the more formal sense of the term (Brock 1990: 25-33. In this, he corroborates the findings of Beck (1958: 298), who concludes that a confusion of monasticism with "the asceticism of the young church" had taken place.

${ }^{9}$ Brock 1975/6: 21-23 cites the disparaging comments of Burkitt and Segal, and attributes their opinions to the fact that they looked in vain for certain biographical and historical references in Ephraim's works.

${ }^{10}$ Murray 1975: 220-3. 
on the dynamic between what is hidden and what is revealed discloses the fundamentally incarnational basis of his thought.

\section{TYPOLOGY AND SYMBOLISM ${ }^{9}$}

The Lucan story of the sinful woman is treated by Ephraim in all three of the verse forms he favours: memre (verse-homilies), madräshe (stanzaic hymns), and sogyäthä (dialogue poems), ${ }^{11}$ which exhibit, perhaps better than his biblical commentaries, the particular theological approach which is his trademark. That, at least, is the opinion of de Halleux. ${ }^{12}$ Regardless of the form chosen, Ephraim's works are moulded by his understanding of types and symbols $^{13}$ as being not just important literary devices, but indicators of the mystery of God's redeeming work. The symbol does not merely represent something other, in a metaphorical sense; at some level it actually constitutes the other. For Ephraim, the hidden meaning of matter (which should not, therefore, be despised) is revealed by the "luminous eye of faith," 14 the process of hidden power known as haylä kasyā.

Ephraim's use of typology, antithesis and other such modes is demonstrated effectively in his treatment of various female characters from the New Testament. They seek healing for their inner and outer selves, healing both from physical infirmity and

${ }^{11}$ Full bibliographical details of the substantial number of studies of typology in Ephraim may be found in Murray's scholarly monograph and full-length study (1975 and 1975/6), and in Brock (1983, especially 37, where he notes that in Ephraim's hands, typology becomes "something of an art form."). McVey 1989: 41 likewise lists numerous modern studies on Ephraim's use of symbols.

12 Detailed definitions of these forms may be found in Brock 1983: 35-45; 1990: 336-39; and 1992: 34.

13 de Halleux 1973: 36. de Halleux's understanding of Ephraim's theology is that he avoids so-called Greek dualism, whilst already being part of "a profound intellectual osmosis" of both Hellenic and Semitic mindsets.

${ }^{14}$ As to the vocabulary used, raza is the most significant single word in Ephraim's work. Brock 1990: 42ff. says that, for the Fathers, raza, "symbol", indicates the connection between two different modes of reality. A symbol actually participates in some sense in the spiritual reality it symbolizes. See also his comments in The Harp of the Spirit (1983) $12 \mathrm{f}$ and of. Murray 1975/6: 8f. 
spiritual disease. With the sinful woman, Ephraim focuses on the process of grief for sin by moving through various stages in the externalization of inner knowledge. This externalization of an inner state is quintessential to Syrian asceticism, ${ }^{15}$ in which purity of heart is valued together with physical purity, and where asceticism is the condition of a heart and mind focused, in covenant with God, rather than the physical anachoresis of other desert ascetics. In all these homilies, it is in the crux between the inner and outer aspects of humanity that the ascetic phenomenon of grief for sin is experienced.

\section{CONFLATIONS AND TYPOLOGY OF WOMANHOOD ${ }^{16}$}

Ephraim draws on the existing Biblical conflation of Luke's "sinful woman" 17 with the woman who anoints Jesus at Bethany ${ }^{18}$ and also with the woman with the haemorrhage. ${ }^{19}$ This conflation is found in the hymns and homilies, ${ }^{20}$ and also in Ephraim's Commentary on Tatian's Diatessaron. ${ }^{21}$ There are also references to the sinful woman

${ }^{15}$ Hymn on Faith 3:5, quoted in Brock 1992: 73 (hence the title of this book). Brock also offers useful explanations of this term in the introduction to his translation of the Hymns on Paradise (1990).

${ }^{16}$ Fitzmyer 1979: 684ff. gives a detailed explanation of the biblical conflations to do with Luke's story of the sinful woman. Ward 1987: $10-25$ cites evidence of medieval conflations of these characters.

17 As well as appearing throughout the two verse-homilies mentioned, this character appears in Hymns on Virginity 4:4 and 35:5, Hymn on the Fast 14 (Rouwhorst 1989, vol. 2: 27-9 and in the Commentary on the Diatessaron 8 and 10, and Hymn 9 on the Church verse 19, (Murray 1980: 38).

${ }^{18}$ Mt 26: 6-13 and Mk 14: 3-10. This conflation in Ephraim may be seen in Hymn on Virginity 4:11, and the Hymn on the Church 9:10 (Murray 1980). Robinson 1997 offers further arguments concerning the shared identity of Mary of Bethany (who he sees as the "Sinner Woman"), and Mary of Magdala.

19 Mt 9: 20-2, Mk 5: 25-34 and Lk 8: 40-8. The woman with the haemorrhage appears in the following texts: Hymns on Virginity 4:7; 26:6; 34:1, Hymn on the Faith 10:5 (Murray 1970: 143), Commentary on the Diatessaron 7, nos. 1, 2, 6, 9, 18, Homily on Our Lord, no. 13.

${ }^{20}$ For example, Hymn on the Faith 10:5 (Murray 1970: 142).

${ }^{21}$ McCarthy 1993: 137 (Book 7, 18). The antithesis between what is hidden and what is revealed is a significant motif in the story of the woman with the haemorrhage and the sinful woman, in this text; note especially McCarthy 1993: 129-31 (Section 7, 1, 2 and 6). As well as 
in connection with the Samaritan woman at the well22 whom Ephraim cites as a model of one healed of impurity by her penitence and faith, being:

$$
\begin{aligned}
& \text { "a type of our humanity } \\
& \text { that He leads step by step." } 23
\end{aligned}
$$

McVey, whose recent translations of a selection of the Hymns is most valuable, suggests that Ephraim's focus on these women is connected with the concept of spiritual brides. She also claims that: "The anointing of Jesus by the sinful woman, perhaps to be identified here with Mary, sister of Martha, is placed in a line with priestly and royal messiahship, as well as being a model of forgiveness." 24

Certainly, there are many references in the Hymns to the virtues of physical and spiritual virginity. The image of the spiritual bridegroom is a significant feature of Syrian asceticism. A number of the hymns focus on the merits of oil, as used in anointing, 25 which also gives weight to McVey's comment.

But close examination of Ephraim's work as a whole reveals a more fundamental reason for the choice of this particular woman, namely the typology of Mary as second Eve. Murray notes that Ephraim adds to the established convention the analogy of the Holy Mother of God and the Church. The name "Mary" becomes, like Kepha, "almost a functional title," he argues. ${ }^{26}$ A Mary was the first person to see the incarnate Christ and the first to seek him in the empty tomb at the end of his incarnate life. McVey follows this train of thought in seeing Ephraim's focus on Marian typology as fundamental to his incarnational theology. ${ }^{27}$

conflations, the different characters are frequently found in juxtaposition to one another, suggesting that the stories are mutually illuminating.

${ }^{22}$ Hymn on Virginity 22:5 and 7 (McVey 1989: 365f). This juxtaposition is repeated in Soghitha 1:5 (Brock 1988: 43).

${ }^{23}$ Hymn on Virginity 22:21 (McVey 1989: 360).

${ }^{24} \mathrm{McV}$ ey 1989: 376.

${ }^{25}$ E.g. Hymn on Virginity 7 (McVey 1989: 275-80; 287-91; 292-6.

26 Murray 1975: 147. Murray 1975: 146 and 330ff also notes the deliberate "fusion" of Mary Magdalene and Mary the Mother of God. See also Murray 1971. For an example of this in Ephraim, see Hymn on Virginity 6:7.

${ }_{27}$ McVey 1989: especially 32-4 and 44-6. Specifically with reference to the sinful woman's anointing, Hymn on Virginity 4:11 notes that the oil 
The Marian typology provides Ephraim and his school with a model for a broader typology. Running parallel to this convention, which is an obvious echo of the Pauline motif of the First and the Second Adam, is a generic typology of womanhood as the heirs of Eve. The women who feature in these homilies and commentaries thus become models of sinning penitents. This is stated explicitly in the first of the anonymous homilies edited and translated by Graffin (1962):

"Blessed are the sinners ... the guilty ones ... the image of Adam," 28 the author writes; "For in calling this one, it is our entire race that he invites to love, and in her person, it is all sinners whom he invites to pardon." 29

The forgiveness offered to the sinful woman is extended, by analogy, to all the faithful penitent, through the institution of the Divine Liturgy, the bloodless sacrifice of the Incarnate Saviour. ${ }^{30}$

The fact of these being women in need of healing is used to a theological end by Ephraim, as attested in Section 15 of part 7 of the Commentary on the Diatessaron, where Ephraim reflects that faith in the incarnation is inspired by the healing of an unclean womb by the one born of a pure womb. ${ }^{31}$ Both the woman with the haemorrhage and the "sinful woman" consciously seek out Jesus,

used "became the bridge to the remembrance of Mary to pass on her glory from generation to generation." (McVey 1989: 279).

${ }^{28}$ Graffin 1962: 179 (1, 1-2).

${ }^{29}$ Graffin 1962: $181(1,4)$. Cf. the comment in the homily edited by Sauget 1975/6: 166 (14): "This name of sinner is effectually a name for of all dirtiness, an image full of impurities". Cf. Hymn on the Nativity 4:40 (McVey 1989: 92): "The sinner who had been a snare for men-He made her an example for penitents." Cf. also the first of Brock's Sogyatha, v. 59, p. 52:

"O Son of God, who opened His mouth and forgave the sinner her sins,

forgive us our sins too, just as you did hers,

for we have sinned just as did she."

${ }^{30}$ Brock's first Soghithā notes this explicitly, v. 60, p. 62:

"And as the sinful woman was forgiven

because she kissed Your feet in Simon's house,

do You forgive Your church

which consumes Your Body and Blood at the altar."

31 McCarthy 1993: 136. 
one covertly, the other openly, with a physical manifestation of an inner need for healing. They demonstrate that they have the "eye of faith" required in order to be open to God. Female sexuality, represented by the hidden gynaecological ailments and the overt sexuality of the supposed prostitute, thus become symbolic of the whole of humanity's need for cleansing and healing by the Second Adam. The healing of mind and body are interdependent because of their indivisibility. ${ }^{32}$ The Syrian tradition elaborates on the gynaecological metaphor by describing sin as sterility, which penitence restores to fecundity, ${ }^{33}$ in the context of becoming a pure bride of Christ.

\section{Grieving Penitence ANd THe Sinful Woman}

[14] In the Syrian tradition represented by these homilies, certain themes and modes of operating recur. The first to be noticed is that the homilies start with a part of the narration not found in the Biblical story as it has come down to us. Ephraim's madräshe introduce the person of Satan as a personification of the sinful woman's former state and of her doubts about her acceptability to Jesus. This allows for extended inner dialogue. The perfume-seller is also introduced in some of these homilies.

The second theme is that the woman's own attributes are the instruments of her healing. Her impurity is transformed through the correct use of her body. The restoration offered to her by Jesus is comprehensive, and heals-rather than spurning as unworthythe woman's physical condition, as well as her soul. The analogy between physical illness and mental or spiritual affliction has already been noted, and the juxtaposition of this story with that of the woman with an issue of blood reinforces this motif.

Both women's love and faith constitute a typology of the mystery of salvation, with the visible redeeming the invisible, through the eye of faith. Symbolism and typology here are more

32 Ephraim expresses this sense of the integrity of the human person in Nisibene Hymn 69:3 (Brock 1983: 77): "You looked upon the body, as it mourned, and on the soul in its grief, for you had joined them together in love, but they had parted and separated in pain."

33 Sauget 1975/6: 164 (3) and 168/9 (31) compares the Penitent sinful woman to Anna, the mother of Samuel. Exactly the same use of metaphor is made by Romanos in Ode 10, 8 (Carpenter 1970: 104). 
than literary devices. They mirror the mystery of salvation, in which the invisible Godhead is manifested through His Incarnate Son, who secretly heals souls and bodies as a symbol of the whole person's restoration to the image of God.

\section{InNer Dialogue and Personification}

[17] Ephraim's Homily on the Sinful Woman starts where the woman weeps for her sins and expresses her determination to change. Having said these things inwardly, "then she began to do [them] outwardly." 34 The two Sogyatha translated by Brock, which he believes to be clearly based on Ephraim's memrä, both constitute a meditation purely on this point of conversion. The woman's conscience engages in dialogue with her old self, personified by Satan. ${ }^{35}$ It is the awakening of her conscience which catalyses the movement of metanoia and leads her to weep at the feet of Jesus.

The homily translated by Sauget makes specific reference to this pricking of conscience which is accompanied by an "interior" repentance. ${ }^{36}$ This text focuses on her inner thoughts, which are expressed not by audible words, but through her eloquent eyes and her tears, ${ }^{37}$ for these speak to Jesus of her grief for her sins. Here, in this moment of spiritual awakening, is found the Syrian equivalent of the Greek katanuxis, expressed not in one discrete word, but in a whole mass of typology and symbolism.

In Ephraim's memrā, Satan appears in several guises. First he appears as one of her former customers, then, realising that he will not be able to dupe Jesus, he appears to Simon, knowing that "secret things are not manifest to him." 38 Satan's role is similar in

${ }^{34}$ Johnston 1898: 326/7 (2, 3).

35 Brock 1988. On page 22 he describes these as "an externalized account, in dramatized form, of the inner pyschological conflict through which the woman might be thought to have gone, with all the arguments for hesitating from her proposed action forcefully posed through the mouth of Satan." Apart from the opening and closing stanzas, the whole of each text explores the rhetorical dialogue between the woman and her conscience, personified as Satan. In both texts, Christ the bridegroom imagery points out the paradox of the purity of the prostitute.

36 Sauget 1975/6: $166 f$.

${ }^{37}$ Sauget 1975/6: 168 (30).

38 Johnston 1898: 338f (10-12). The antithesis between hiddenness and openness recurs throughout Ephraim. Here, it is used to indicate the 
Nisibene Hymn 60, ${ }^{39}$ in which he berates the woman for abandoning him. Both in this hymn, and in Soghithā one, Satan acknowledges the superior power of Jesus. ${ }^{40}$

\section{Anointing as Prefiguring Christ's Saving Death}

[20] Mention has been made of the seller of unguents ${ }^{41}$ who tempts the woman to return to her sinful way of life. This interpolation serves two purposes, firstly to emphasise the inner struggle of the woman's conscience with various worldly concerns, as well as with her sense of unworthiness. Secondly, it elaborates on the theme of anointing, which, through the conflation with story of the anointing at Bethany, constantly reminds the reader that Christ died for these sins and that the woman's anointing of him prefigured his death. Hymn on the Epiphany 3 is explicit about this..$^{42}$ The theme of anointing is also used to stress the majesty of Christ as Son of God: this is a major theme in the Hymns on Virginity, for example, Hymn on Virginity, 4:7 and 11:

"An abundance is oil with which sinners do business: the forgiveness of sins. By oil the Anointed forgave the sins of the sinner who anointed [his] feet. With [oil] Mary poured out her sin upon the head of the Lord of her sins... It became the bridge to the remembrance of

blindness of Simon the Pharisee to the true nature of the woman's repentance and his questioning of the prophetic wisdom of Jesus (Luke 7:39), which is commented on also in the Homily on Our Lord (Johnston 1898: 3311 and elsewhere).

${ }^{39}$ Johnston 1898: 212f.

40 In the latter, Jesus is referred to throughout as "Mary's son."

${ }^{41}$ In Ephraim's homily, the perfume-seller is introduced before the figure of Satan. (Johnston 1898: 337 (4 and 5)) Sauget's homily reduces this character to one phrase, but elaborates on the theme by comparing the preciousness of the ointment purchased with the pearl of great price bought by the merchant, an interpolation into the Lucan text which emphasises the woman's awareness of the uniqueness of Jesus, and the significance of her act in anointing Him. The theme of the purchase of ointment is the focus of Mahr 1942, which notes that this incident is not actually mentioned by Luke.

42 Johnston 1898: 269 (1-3). This part of the hymn also uses the visible/invisible paradox which is a recurring motif in Ephraim. 

Mary to pass on her glory from generation to
generation." 43

In Ephraim's treatment the anointing acquires a typology of its own. It is the chrism of the Son of God, the memorial of his saving death, the image of healing and purification. ${ }^{44}$ The sinful woman, in anointing Jesus, represents the one who recognizes Jesus' divinity, his power to save, and his ability to restore the lost image of God to soiled humanity. ${ }^{45}$ This again makes her a type for all penitents. Her experience of penitence leads directly to the grief which she expresses in her tears.

\section{The Transformation EfFected by Healing}

[22] A recurrent motif in the Ephraimic tradition is the analogy between sin and illness. It opens Ephraim's Homily on the Sinful Woman $^{46}$ and is echoed in the second of the homilies edited by Graffin (1962), which opens with a description of the longing of the invalid for health, and how this is exactly the situation of the penitent sinner, who is "sick from sin." This author attributes her suffering to her remembrance of her sins, which is worse than the superficial suffering of her shameful face. ${ }^{47}$ Jesus, in his mercy and wisdom, offers appropriate healing to those who seek him

43 McVey 1989: 278/9.

44 Note especially Hymn on Virginity 6:7 (McVey 1989: 289/90):

"The oil jar she poured on Him emptied out a treasury of types on Him.

In that moment the symbols of oil took shelter in the Anointed,

and the treasurer of the symbols of oil completed the symbols for the Lord of symbols."

45 "Mary by the oil showed forth the mystery of His mortality, Who by His teaching mortified the concupiscence of her flesh." Homily on Our Lord 47 (Johnston 1898: 326).

46 Johnston 1898: 336 (1). There are many references in these homilies and in Ephraim's hymns to Jesus as the "physician of souls," who offers the "medicine of life." Homily on Our Lord 15 (Johnston 1898: 311).

${ }^{47}$ Graffin 1962: 197/9 (4). 
out, ${ }^{48}$ and calls on the faith of those who seek, be they leper, paralytic or sinner. ${ }^{49}$

This analogy is developed in the case of the sinful woman. It is emphasized that the very physical attributes which had been used to charm her clients are the instruments of her salvation. Her humanity is transformed through her correct use of her body. ${ }^{50}$ Her body becomes the sacrifice of a contrite heart (Ps. 51:17), with the tears flowing in place of blood, and the mortified flesh and skin represented by her hair. ${ }^{51}$ Her approach to Jesus is overtly physical: she washes his feet, "the symbol of his incarnation." 52

The dual nature of Christ is mirrored by his receiving both physical and spiritual offerings, the table of food from the Pharisee, and the "table" of penitence from the woman. ${ }^{53}$ The healing he

${ }^{48}$ Graffin 1962: 183 (1:8).

49 The comparison between the effective faith of the sinful woman and that of those in need of more purely physical healing is made in Sauget 1975/6: 173 (64).

50 Homily on Our Lord 14 (Johnston 1898: 310), cf. Sauget 1975/6: 169 (33-6) and 174 (75-81); Brock 1988: 49-51 (1:42-51). The woman herself is aware of this paradox: "The mouth that has kissed the lewd, forbid it not to kiss the body that remits transgressions and sins." Homily on the Sinful Woman 15 (Johnston 1898: 340). Cf. Hymn on Virginity 35:6 (McVey 1989: 417):

"By that thing by which she was lost, she was found, since she believed,

so that triumphant was the oil that had condemned her, and sanctified was the mouth that had defiled her, and purified was the beauty that had debased her."

51 Graffin's 1962: 191 (1:22f).

52 Graffin's 1962: 189 (1:19), and note McCarthy 1993: 170 (Section $10(9))$. Several passages in the Old Testament suggest that 'the feet' was a Hebrew euphemism for the genitals. It is possible that a reader familiar with Hebrew idiom would have made this association and wondered whether Jesus possessed not only a body, but also sexual desire (which might well be aroused in the circumstances described by Luke). However, a passage in the Nisibene Hymn 35 shows that Ephraim, at least, exempted Jesus from the sexual desire which is in all other bodies, 'awake in them even when they are asleep.'

53 Sauget 1975/6: 170 (41f), of. Graffin 1962: 183-5 (no. 1, 9, 10). The double nature of the offering is enforced through the comment that the Pharisee's pride caused him to invite Jesus to his table, but not into his heart. The woman, on the other hand, out of her penitent humility, offers 
gives is of the whole person, and the woman with the haemorrhage is mentioned again, to emphasise the completeness of the healing offered. ${ }^{54}$ It is the woman's initiative which makes possible the gracious act of forgiveness; through washing she is washed, and in washing something pure, she is herself purified. ${ }^{5}$

The woman's body is thus used appropriately now, and its integrity with her soul and mind means that all aspects of herself are sought out and healed. Ephraim's Homily on Our Lord states explicitly that the grief which accompanies the woman's actions is used by Jesus to heal her particular wound of sin:

"These medicines the sinful woman offered to her Physician, that by her tears He might wash away her stains, by her kisses He might heal her wounds, by her sweet ointment He might make her evil name sweet as the odour of her ointment. This is the Physician who heals men by the medicines which they bring to Him." 56

In other words, the woman has within her the source of her own healing. Her insight enables her to present herself to the physician as "the gift which He calls secretly." ${ }^{57}$ Her repentance leads her to both grief at her sins, and the confidence that she is worthy of forgiveness and that Jesus has the power to effect this restoration.

Ephraim's gloss on this aspect of the story is that the prophetic power of Jesus, which is questioned by Simon the Pharisee, is demonstrated by her movement from sinner to penitent, in silent supplication. Her belief that Jesus would know, without her speaking, why she wept, showed that she had "the eye of faith." This is "the power that changed her." 58 Her wisdom ${ }^{59}$ and faith is contrasted with the blindness of the Pharisee, who, in not

her whole self to Jesus for his healing touch. The Pharisee's riches are purely those of the world, while her apparent poverty conceals the riches of her heart.

${ }^{54}$ Homily on Our Lord 13 (Johnston 1898: 310) and Homily on the Sinful Woman 11 (Johnston 1898: 339).

55 Sauget 1975/6: 170 (40).

56 Johnston 1898: 324 (43).

${ }^{57}$ Graffin 1962: 185 (1:11).

58 Johnston 1898: 324 (43).

59 A quality stressed in Graffin 1962: 189 (1:18). 
recognizing Jesus to be a prophet, "was himself proved not to know the Prophets" despite his learning. ${ }^{60}$

\section{THE EYE OF FAITH}

[28] In the Homily on the Sinful Woman Ephraim repeatedly refers to Jesus as: "He Who knows what is secret." ${ }_{11}$ The "interior eye of his divinity" 62 enables him to see that the woman's soul is predisposed towards penitence, and a parallel interior vision on the part of the woman enables her to recognize Christ as the Lord, and to ask him for spiritual healing. Through her physical act in anointing Jesus' feet she knows he is truly man. ${ }^{63}$ The prayer that she offers ${ }^{64}$ makes it explicit for the reader that it is through the manifestation of His humanity that she dares to approach God.

This exchange of unspoken recognition between Jesus and the sinful woman becomes externalized, in order to provide evidence of Jesus' humanity and divinity. Ephraim elaborates on this in the Homily on Our Lord: 65 it is when infirmities are brought into the open that they can be healed; the visible healing symbolizes the invisible healing of forgiveness. ${ }^{66}$ Reference to this may also be found in Hymn on Virginity 46:

${ }^{60}$ Homily on Our Lord 42 (Johnston 1898: 323), cf. Graffin 1962: 185 (1:11). The Commentary on the Diatessaron 10 (10) notes: "He brought the faith of this woman out into the open with praise, but unmasked the thoughts of Simon with reproach. He was a physician to her that believed, for it is he who heals everyone." (McCarthy 1993: 171). The contrast between the actions of the sinful woman and the Pharisee feature in all these homilies, as a model of the antithesis between insight and blindness, humility and arrogance, true and false love, etc. Note Graffin 1962: 209 (2:23f etc.).

${ }^{61}$ Johnston 1898: 340 (14f); of. 338f (10). Sections 3 and 4 use the antithesis of the woman's secret and open actions.

${ }^{62}$ Sauget 1975/6: 164 (4).

${ }^{63}$ Graffin 1962: 189 (1:19).

${ }^{64}$ Graffin 1962: 189/91 (1:20).

${ }^{65}$ Johnston 1898: 312-4 (18-21).

${ }_{66}$ The Commentary on the Diatessaron notes, with regard to the woman with the haemorrhage, who is juxtaposed to the sinful woman, that: "By means of a woman whom they could see, they were enabled to see the divinity which cannot be seen. Through the Son's own healing his divinity became known, and through the afflicted woman's being healed her faith was made manifest" (McCarthy 1993: 129 (7, 1)). 


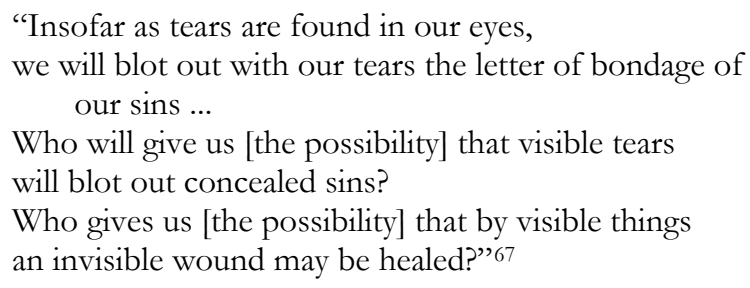

For Ephraim, the ultimate example of the invisible made visible is the Incarnation. The forgiveness shown to the sinful woman is thus inextricably linked with the manifestation of God's divinity through the person of Jesus Christ. In these homilies, this soteriological epiphany stands as one of the author's key theological insights.

\section{HEALING AS DEMONSTRATIVE OF THE INCARNATION}

The desire and the ability of Jesus to heal humanity reveals His divine power. His humanity makes it possible for those in need of healing (spiritual and physical) to approach the Godhead. In the first of the homilies edited by Graffin (1962) this is pointed out by the use of transferred epithets; Jesus is seen as the one who "thirsts," (like the Samaritan woman at the well, who is mentioned there) ${ }^{68}$ for sinners to come to him. ${ }^{69}$ The human attribute of hunger is applied to him to show how much he longed for the woman to be restored:

"Because of her who craved pardon, He wished himself to hunger at the table of Simon the Pharisee; just as

${ }^{67}$ McVey 1989: 450 (12-15).

${ }^{68} \mathrm{Jn}$ 7:37 is also referred to in Ephraim's Homily on Our Lord, in an image of the "healing fountain" offered by Jesus to all sinners (Johnston 1898: 323 (41)).

${ }^{69}$ Graffin 1962: 181 (1:7). The author describes how she had been like stone, but through her penitence, now opens up from her soul "the source of repentance." The language of hunger and thirst for a spiritual condition recalls the beatitudes" "Blessed are those who hunger and thirst for righteousness." Portraying Jesus as one who craves in this way gives him human attributes, which are used to divine end, in that it is his desire to reconcile the sinner which effects the Incarnation, and restores the lost image of God. The language of the beatitudes is overtly use in "Hymn 26 on Virginity," where the sinful woman, the woman with the haemorrhage and others are addressed as "Blessed" (McVey 1989: $378(4,6))$. 
under the cover of a table of bread, He had prepared for the sinful woman a table of penitence." 70

The author gives as Jesus' reason for accepting Simon's hospitality that He hungers for the life of Man, that He may recover his lost image. ${ }^{71}$ This transference of epithets continues with a overtly kenotic description of the woman "emptying her soul" so that God can fill it, whereas the Pharisee only fills his table for Jesus to empty it. ${ }^{72}$ The sinful woman, seeking wholeness, is thus compared to God seeking to express his whole nature through the Incarnation. The broken-hearted sacrifice of herself is mirrored by Christ's self-sacrifice in the sacrament of the Divine Liturgy.

This homily is framed by references to God seeking out his lost image: it is subtitled "God seeking out his creature and his image," and, at the end of the homily, the concern of God to reclaim His image is mentioned again. ${ }^{73}$ In restoring the fallen to the image of God, grieving penitence becomes the embodiment of the healing offered by the embodied Lord. The healing is the outward manifestation of the inner state of sorrow for sins, being the result of the grief at having lost the image of God.

The antithesis: inner/outer states of being is expressed by the dynamic: visible/invisible, as demonstrated in the Incarnation. The actions of the sinful woman are described by the author of Graffin's first homily as enabling the invisible to become visible, in order to help humanity understand the true nature of its Saviour:

"it is because the eye of man cannot grasp His essence that God showed himself bodily in creation, so that

${ }^{70}$ Graffin 1962: 181 (1:5), of. Sauget 1975/6. This homily shares with Sauget's the image of the woman as an innocent lost sheep, in need of the Shepherd.

${ }^{71}$ Graffin 1962: 81 (1:6f).

72 Graffin 1962: 185 (1:11). The antithesis between the woman and the Pharisee is a recurring motif in this and the second homily edited by Graffin, in which it is stressed that his love for Jesus is purely human, whereas hers is more sanctified because she recognizes Him for who $\mathrm{He}$ is. Graffin 1962: 209 (2:25). Her humility is set in opposition to the pride of the Pharisee, and her recognition of the divinity of Jesus is opposed to the blindness of the Pharisee who questions whether Jesus is truly a prophet.

${ }^{73}$ Graffin 1962: 193 (1:25). 
those who could not see Him as God, could see Him in the man, with their bodily eye."74

The feet which she bathes with her tears are "the symbol of his Incarnation" 75 and the relationship established between her and Jesus through this very human action gives her proof that He was truly man. ${ }^{76}$ The synthesis of human need and divine gift is brought out vividly in the relevant passage of Ephraim's Commentary on the Diatessaron: ${ }^{77}$

"His humanity was washed by her tears and was refreshed, while his divinity granted redemption there and then for the price of her tears. Only his humanity was capable of being washed, whereas his divinity alone could expiate the sins which were not visible."

The woman's faith, love and penitence are often the focus in these homilies. The emphasis on her experience of mourning for sin is one of grieving penitence rather than penitent grief. The grief is very much the vehicle of her awakened conscience, rather than an end in itself. The Syriac texts are concerned with the involvement of her heart in this experience, the quality of the emotion she experiences at being so distanced from God. Arising as it does from the heart, this grief is rooted in the centre of the human being, as understood by the Syrians. Her outpouring of tears is described, rather than analysed:

${ }^{74}$ Graffin 1962: 189 (1:18), cf. Hymn on the Nativity 27:8 (McVey 1989: 212): "He showed the hidden by way of the revealed." and 4:7 (McVey 1989: 277), which recalls the anointing theme again:

"When they anointed and healed by oil, the Anointed was portrayed in secret, and He persecuted all ills, as on the hem of the garment the flow of blood saw Him and dried up."

75 Graffin 1962: 189 (1:19).

76 Graffin 1962: 189 (1:19). The second homily of Graffin devotes some space to the issue of Christ's accessibility to humanity through his human form (Graffin 1962: 311 (2:28)) and various instances of his being received as God during his earthly ministry are cited, including the healing of the woman with the haemorrhage (Graffin 1962: 312).

77 McCarthy 1993: 170 (Section 10, 8). 
"she gave abundantly the tears from her eyes; there was in her heart a source of continual tears and in her soul, groanings without end." 78

The intimacy in the encounter between Jesus and the sinful woman brings out the relationship between human sin and the sufferings of Christ, whose death atones for sin. The juxtaposition of the story of the anointing at Bethany reinforces this. Mourning for sin is set, in these Syriac homilies, in the context of God's desire to reconcile humanity, to offer healing through the salvation of Christ. The nature of the Syriac language predisposes Syriac authors to the use of antithesis, typology and symbolism, which imply the Biblical typology of Jesus as Second Adam and the revelation of the hidden power of God. The grieving penitence of the sinful woman provides her with her own route to wholeness; her body, put to honourable use, is the vehicle for the healing of her soul. Despite a background of often severe asceticism and abhorrence of the sexual function of the body, these homilies, in the hands of Ephraim and his imitators, reveal a most compassionate and constructive view of the sinful woman. ${ }^{79}$ As a Type of sinful humanity, she is to be identified with by all people. The love expressed by her for Jesus, and his loving response, is the model for Christian discipleship, rather than the uprightness of the Pharisee.

The distinctive contribution by Ephraim and his school to the exegesis of this text, lies in the reinterpretation of womanhood as a crucial exegetical symbol of redemption. In these homilies, female sexuality is presented as symbolic of all humanity's need for the healing offered by Christ. The woman's body, as we have seen, becomes the instrument of her own healing, a symbol of the redemption afforded by the body of Christ, broken on the Cross and in the Holy Eucharist. The sterility of sin is replaced by the fecundity of penitence. The use of Marian typology thus goes far beyond the association of women with the fallen state. In symbolising sinful humanity, the woman also symbolises the Mary who was the bearer of the Incarnate Christ and the Mary who was the first to seek Him in his Risen Life. Her conscious

${ }^{78}$ Graffin 1962: 195 (1:27).

${ }^{79}$ This dynamic is clearly expressed in Luke's telling of the story; it is significant that Ephraim and others were so keen to focus on this story. 
acknowledgement of her need for healing enables her inner eye of faith to recognise the glory of Easter morning. Ephraim and his followers thus contribute unique insights into an inclusive theology of redemption.

\section{REFERENCES}

Brock 1975 Brock, S. "St. Ephrem on Christ as Light in Mary and the Jordan," Eastern Churches Review 7 (1975): 137-44.

Brock 1983 Brock, S. The Harp of the Spirit (Studies supplementary to Sobornost, no. 4; 1983).

Brock 1988 Brock, S. "The Sinful Woman and Satan: Two Syriac Dialogue Poems," Oriens Christianus 72 (1988): 21-62.

Brock 1989 Brock, S. Spirituality in the Syriac Tradition (Kottayam, 1989).

Brock 1990 Brock, S. St. Ephrem the Syrian: Hymns on Paradise (Crestwood, NY, 1990).

Brock 1992 Brock, S. The Luminous Eye: The Spiritual World Vision of Saint Ephrem the Syrian (Cistercian Studies 124; Kalamazoo, 19922).

Budge 1904 Budge, E. A. W. The Book of Paradise, 2 vols. (London, 1904).

Carpenter M. Carpenter (tr.), Kontakia of Romanos, vol. 1 (Columbia, 1970 1970).

Fitzmyer Fitzmyer, J. "The Gospel According to Luke," ch. i-ix 1979 Anchor Bible Commentary (New York, 1979).

Graffin 1962 Graffin, F. "Homélies anonymes sur la pécheresse," L'Orient Syrien 7 (1962): 175-22.

Hartranft Hartranft, C. D. "Sozomenus: Ecclesiastical History," 1890 A Select Library of the Christian Church, Nicene and Post-Nicene Fathers, 2nd Series (United States: Christian Literature Publishing Company, 1890).

Jackson 1892 Jackson, B. "Theodoret: Ecclesiastical History," A Select Library of the Christian Church, Nicene and Post-Nicene Fathers, 2nd Series, vol. 3 (United States: Christian Literature Publishing Company, 1892).

Johnston Johnston, A. E. "Ephrem's Homilies on Our Lord, 1898 Admonition and Repentance, and The Sinful Woman," A Select Library of the Christian Church, Nicene and Post-Nicene Fathers (Second Series), vol. 13 (United States: Christian Literature Publishing Company, 1898). 
Mahr 1942 Mahr, A. C. Relations of Passion Plays to St. Ephrem the Syrian (Columbia University Press, Ohio, 1942).

McCarthy McCarthy, C. "St. Ephrem's Commentary on Tatian's 1993 Diatessaron," JSS Supplement no. 2 (1993).

Murray 1975 Murray, R. Symbols of Church and Kingdom (Cambridge, 1975).

Murray 1976 Murray, R. "The Theory of Symbolism in St. Ephrem's Theology," Parole de l'Orient 6-7 (1975-76): 1-20.

Murray 1980 Murray, R. "St. Ephrem's Dialogue of Reason and Love," Sobornost 2. (1980): 26-40.

McVey 1989 McVey, K. Ephrem the Syrian: Hymns, Classics of Western Spirituality (New York, Mahwah, 1989).

Outtier 1973 Outtier, B. "Saint Éphrem d'après ses biographies et ses oeuvres," Parole de l'Orient 4, nos. 1-2 (1973): 11-33.

Robinson Robinson, B. P. "The Anointing by Mary of Bethany," 1997 Downside Review (April 1997): 99-111.

Sauget Sauget, J. H. "Une homélie syriaque anonyme sur la 1975/6 Nativité," Parole de l'Orient 6-7 (1975-76): 159-194.

Ward 1987 Ward, B. Harlots of the Desert (Cistercian Studies 106; Kalamazoo, 1987). 